\title{
MASSIFICATION OF HIGHER EDUCATION IN MALAYSIA: CHALLENGES FACING PUBLIC SCHOOLS
}

\author{
Arnida Abdullah \\ Universiti Putra Malaysia, Malaysia \\ E-mail: arnidaa@upm.edu.my
}

\author{
Received: $01^{\text {st }}$ May 2018; Revised: $27^{\text {th }}$ November 2018; Accepted: $28^{\text {th }}$ December 2018
}

\begin{abstract}
Higher education plays an important role in many developing countries. Graduates are being equipped with professional knowledge and skills to fulfil the demands of the labour market in a knowledge economy. Malaysia is amongst those developing nations that have looked to advanced economies to provide a model of mass higher education which would raise educational levels and national income. Since the 1990s, therefore, the government has been expanding the higher education sector and broadening access to higher education institutions. Its goal is to boost higher education enrollments rate from 48 percent to 70 percent by the year 2025 (Ministry of Education Malaysia, 2015). The need to respond to this expansion of higher education enrolments has implications for all three levels of school education - primary, lower secondary and upper secondary. Using secondary data, this study aims to explore challenges currently facing public schools in order to produce graduates with good academic results that enable them to gain a place in higher institutions. The findings of this study have provided evidence that school education system is still facing great challenges. A key to making higher education more effective, therefore, is to strengthen and improve Malaysia's public schools.
\end{abstract}

Keywords: massification; higher education; Malaysia; public school

\section{Abstrak}

Pendidikan tinggi memainkan peran penting di banyak negara berkembang. Para lulusan sedang dilengkapi dengan pengetahuan dan keterampilan profesional untuk memenuhi tuntutan pasar tenaga kerja dalam pengetahuan ekonomi. Malaysia adalah salah satu negara berkembang yang telah mencari ekonomi maju untuk menyediakan model pendidikan tinggi massal yang akan meningkatkan tingkat pendidikan dan pendapatan nasional. Sejak 1990-an, oleh karena itu, pemerintah telah memperluas sektor pendidikan tinggi dan memperluas akses ke institusi pendidikan tinggi. Tujuannya adalah untuk meningkatkan tingkat pendaftaran pendidikan tinggi dari 48 persen menjadi 70 persen pada tahun 2025 (Departemen Pendidikan Malaysia, 2015). Kebutuhan untuk menanggapi perluasan pendaftaran pendidikan tinggi ini berimplikasi pada ketiga tingkat pendidikan sekolah-sekolah dasar, menengah bawah, dan menengah atas. Penelitian ini bertujuan untuk mengeksplorasi tantangan yang saat ini dihadapi sekolah umum untuk menghasilkan lulusan dengan hasil akademik yang baik yang memungkinkan mereka mendapatkan tempat di institusi yang lebih tinggi. Temuan penelitian ini telah memberikan bukti bahwa sistem pendidikan sekolah masih menghadapi tantangan besar. Oleh karena itu, kunci untuk membuat pendidikan tinggi lebih efektif adalah memperkuat dan meningkatkan sekolah-sekolah negeri di Malaysia.

Kata kunci: massifikasi; pendidikan tinggi; Malaysia; sekolah umum

How to Cite: Abdullah, A. (2018). Massification of Higher Education in Malaysia: Challenges Facing Public Schools. TARBIYA: Journal of Education in Muslim Society, 5(2), 225-235. doi:10.15408/tjems.v5i2.8118.

Permalink/DOI: http://dx.doi.org/10.15408/tjems.v5i2.8118 


\section{Introduction}

Malaysian education system has grown significantly since Malaysia became an independent nation in 1957, commencing from the First Malaysian Plan (1MP) which covers the period from 1966 to 1970. A considerable amount of effort in expanding access to education has been documented in every fiveyear development plan in order to unify the three main ethnic groups which are Malays, Chinese and Indians, and most importantly, to develop human resource capacity in accordance with the economic needs of the country. For that reason, the education system has experienced several transformations to create a strong, high quality structure to the national school system and to ensure that it meets the diverse learning needs of all students. The changes are important to ensure that students are gaining essential knowledge, learning core skills, reaching their highest potential and achieving the highest level of education possible.

From the First Malaysia Plan (1966-1970) until the Eleventh Malaysia Plan (2016-2020), Malaysian government has achieved remarkable success in expanding primary and secondary education. The number of students enrolled in public schools has been rising over many decades and the number of schools are also growing. The increasing number of students attending primary and secondary education are more likely come from a much wider and diverse cross-section of society and this situation should deliver more students to higher educational institutions.

The Malaysian government has set itself the goal of increasing participation rates in higher education institutions which comprising of public universities, polytechnics, community colleges, private universities, private university colleges, and private colleges. Since the 1990s the government has been expanding the higher education sector and broadening access to higher education institutions. Its goal is to boost higher education enrollments rate from 48 percent in 2012 to 70 percent by the year 2025 (Ministry of Education Malaysia, 2015). The need to respond to the expansion of higher education enrolments has implications for all three levels of school education - primary, lower secondary and upper secondary.

\section{Massafication of Higher Education}

A clear and strong correlation between economic growth and education has encouraged the Malaysian government to pay particular attention to the national education system, both school and higher education. In the First Malaysia Plan, the government expanded enrolments from the basic 6-year primary education to three years of lower secondary school. Later, they increased the number of places at two-year upper secondary school and finally at post-secondary and higher education. The rapid growth in each level of education has been counterbalanced by equally rapid economic development in Malaysia. Thus, Malaysia successfully developed from a commodity-based economy in the 1960s to one focused on manufacturing sector in the 1980s and later services. In recent years, however, the government has placed greater emphasis on becoming a knowledge-based economy, in line with Malaysia Vision 2020 which was proposed by the fourth Prime Minister, Tun Dr. Mahathir Mohamad in 1991. Realizing the important role of higher education in contributing to the development of the country, Malaysia has already taken the road to mass higher education.

Massification of higher education is based on the principle that higher education should be widely accessible and should cater for a more diverse range of students. The government, therefore, has developed strategies for expanding the higher education sector, including increasing the number of TVET institutions, upgrading 
several public and private non-university institutions to fully fledged university status, coopting the private sector and implementing institutional diversification. These strategies have been implemented to ensure more equitable access to higher education for all students through a variety of pathways.

The new system of mass higher education has led to positive impacts on the Malaysian higher education industry in terms of the vastly increased numbers of students enrolled in higher education and the range of higher institutions available to them. Looking at the present system of the higher education, as shown in Figure 1, the government seems determined to create a multi-tiered system that offers a place to all students, though the places differ in access and impact.

As can be seen in the above diagram, the Malaysian tertiary education system has multiple tiers and is divided between public and private providers. The left hand side of the graph shows public tertiary institutions. These include public universities, polytechnics and community colleges. The right hand side represents private tertiary institutions. These consist of private local universities, private foreign universities, private university colleges and private colleges. Of the total number of students enrolled in 2015, $655,255(57 \%)$ were at public higher institutions and $493,926(43 \%)$ were at private higher institutions. At public higher institutions, $47 \%$ of students enrolled at public universities, while $10 \%$ at technical and vocational institutions. The same situation existed at private higher institutions when more students enrolled in private universities $(27.7 \%)$ as compared to private colleges $(15.3 \%)$. It is the aim of the government to increase the number of students enrolling in public and private higher institutions to 2.5 million $(70 \%)$ by the year 2025, which includes 250,000 target-setting for international student.

Figure 1. Higher education structure by local student enrolment and number of institutions, 2015

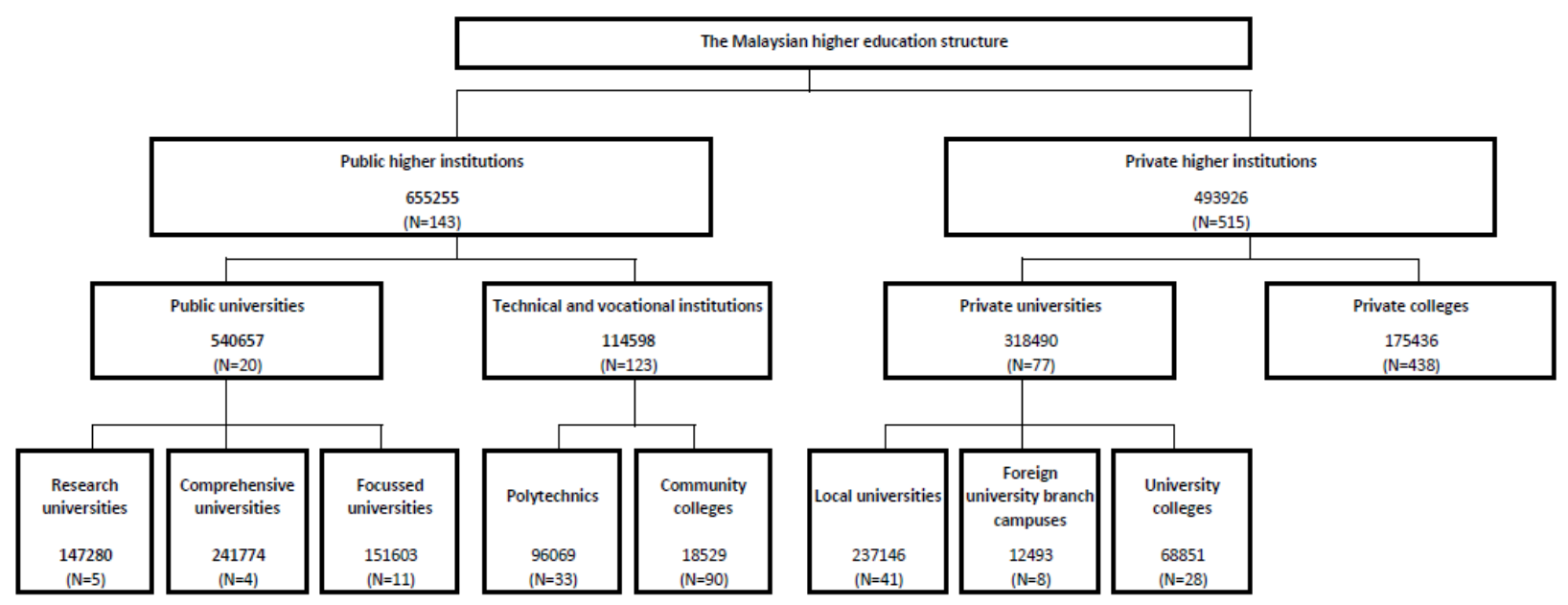

Source: Ministry of Higher Education (2015)

Note: The information with ' $N$ ' refers to the number of institutions and the numbers above refers to the enrolment 
The growth of these institutions has also led to many changes in the role and functions of each institution in the multi-tiered system in response to the rapid economic changes and the needs of the society. The research universities are expected to provide a world-class university education and become members of the exclusive group of world-class universities. On the other hand, comprehensive and focussed universities aim at increasing participation and widening access to higher education. Polytechnics, for their part, have been entrusted to produce more skilled workers and semi-professionals mainly in technical fields. Community colleges provide skills and vocational training. Private tertiary institutions, on the other hands, are mixed. Some foreign and local private universities have high status, but there are many local and small colleges. These private providers attract more overseas students than their public counterparts, probably due to the foreign degree programs offered jointly with international partners and the use of English for teaching in class.

\section{Progress Towards Building Primary and Secondary Education}

Primary level is the first level of education at which children acquire basic literacy and numeracy. The next stage, secondary education, trains them more deeply in developing skills, identifying potential and building their strengths in an area which interests them most as they study a range of subjects in science and humanities. At this stage, they are able to choose a variety of routes with teachers providing essential support to boost their strength and confidence in their own abilities. As a bridge between primary and tertiary education, secondary education is a stage of preparation for students to learn a basic academic specialisation and to demonstrate academic achievement which will determine entry to higher institutions. In view of that, the development of primary and secondary schools has been a stated priority in every five-year development plan since the $1 \mathrm{MP}$ and physical resources have been expanded in schools to accommodate enrolment growth. One of the programs by the government, as reported by Wong and Ee (1971) was, "a series of 'crash programs' to build new classrooms and provide teachers and educational facilities."

The rapid expansion in primary and secondary education has occurred due to large increases in government spending since the $1 \mathrm{MP}$. The strong economy has allowed the Malaysian government to consistently increase expenditure in the primary and secondary school levels of education over the last 44 years, as shown in Figure 2.

Figure 2. Allocation of development expenditure for primary and secondary education, 1966-2010 (in RM millions)

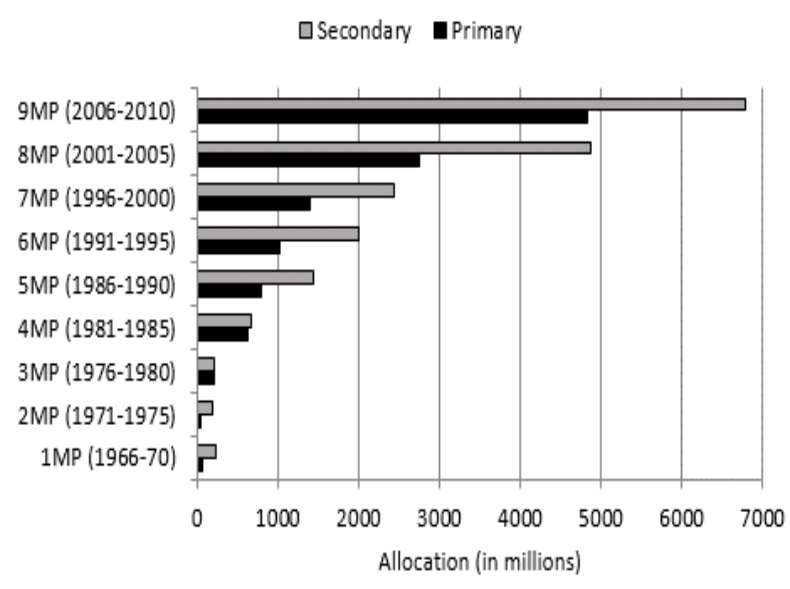

Source: Malaysia (various Plans)

Note: Technical and vocational education is included in the allocation for secondary schools in $2 \mathrm{MP}, 3 \mathrm{MP}$ and $4 \mathrm{MP}$ because it was then categorised as upper secondary education

Figure 2 shows the expenditure on primary and secondary education. The total investment by the government on primary and secondary education over the last 44 years was RM30.598 billion. Secondary education has received the largest share of development expenditure in every Malaysia Plan, totalling RM18.84 billion 
over the 44 years. The increase in expenditure on primary and secondary education has resulted in the growing number of schools. Figure 3a shows the number of public primary and secondary schools between 1958 and 2017 and Figure 3b reports the percentage growth of both types of school over the same period.

Figure 3a: Number of primary and secondary schools, 1958-2017

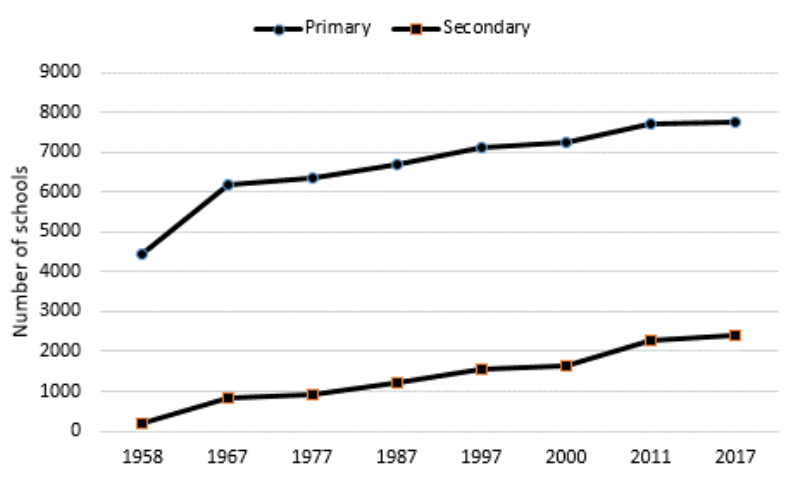

Source: Ministry of Education (2008), Wong \& Ee (1971) \& Ministry of Education website (2017)

Figure 3b: Index of primary and secondary schools, 1958-2017

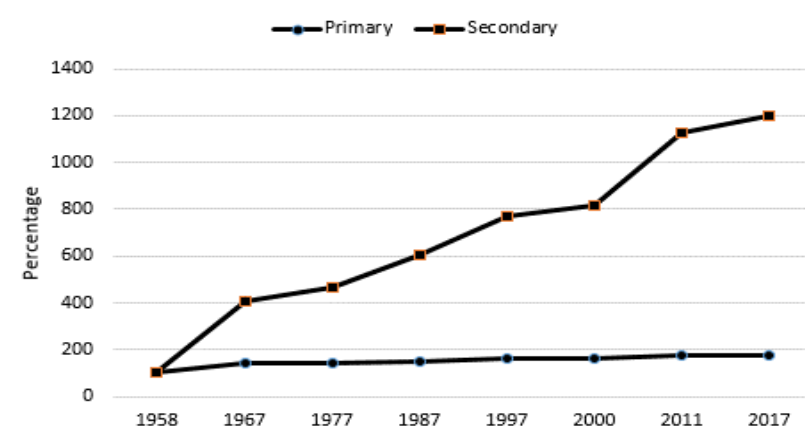

Note: $1958=100$

As can be seen from Figure 3a, the overall number of primary schools was higher than secondary schools between 1958 and 2017, increasing from 4,430 units in 1958 to 7,772 units in 2017. Secondary schools increased in number from 201 units to 2,408 units during the same period. Figure 3b, on the other hand, illustrates that secondary schools experienced a growth rate of more than 1000 percent between 1958 and 2017, as compared to the growth rate for primary schools which was about 175 percent. These increases in number of primary and secondary schools have enabled the government to meet the accelerating demand for primary and secondary education.

The rapid increase in the number of schools, particularly in rural and remote areas, and mainly in Sabah and Sarawak, led to a similarly marked increase in student enrolments. In addition, due to the effectiveness of several programs which have been carried out since the $1 \mathrm{MP}$, school attendance has improved over the past few decades. Figure 4 shows the number of students enrolled in primary and secondary schools between 1963 and 2017.

Figure 4. Primary and secondary enrolments, 1963-

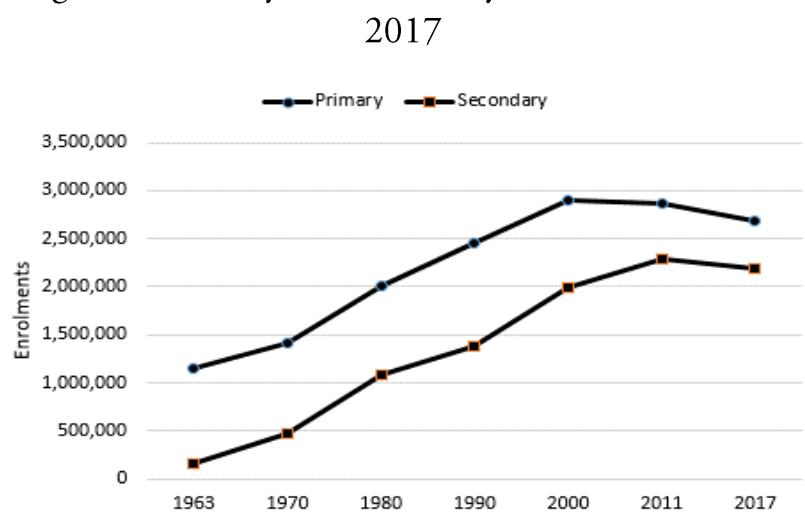

Source: Ministry of Education (2008), Wong \& Ee (1971) and \& Ministry of Education website (2017)

As shown in Figure 4, enrolment rates in primary increased significantly over the last 37 years but started declining in 2000. Secondary school enrolments, on the other hands, experienced an upward trend over the last 48 years and then started to decline between 2011 and 2017. Enrolments in primary schools recorded an increase from approximately 1.1 million in 1963 to about 2.6 million in 2017 , while the secondary school enrolments rose from 155,143 to 2.1 million during the same period. Looking into the growth rate between primary and secondary schools from the base year 1963, secondary enrolments have expanded at a rapid pace compared to primary enrolments. In 2017, the enrolment growth rate in secondary 
education was 1,411 percent and the primary education rate was 234 percent. This indicates that secondary enrolments in 2017 were 1,311 percent more than it was in 1963 , while primary enrolments were only 134 percent more in the same period.

The government's efforts in increasing the school participation by children aged six to seventeen have seen a good progress. The downward trend of falling enrolments in primary and secondary schools in recent times, however, is such a growing concern. If the downward trend continues, the current school system may not achieving the desired participation rate which will have a tremendously negative impact on Malaysia's development and its goal of becoming a high income, developed nation by the year 2020

\section{Method}

This study focuses on secondary source of data. This type of data involved the use of existing data that have been collected by other researchers for some other purposes (Boslaugh, 2007). The re-use of existing data may lead the researcher toward a new understanding, or even an unexpected finding (Anderson et al., 2011) since it is much more suitable to better understand and to examine patterns. The data collected was then edited, and converted into tables, charts or figures to look for patterns and trends.

\section{Results and Discussion}

\section{Challenges Facing Public Schools}

Mass higher education has brought with it many challenges and created pressure on all school institutions to produce school leavers with good academic results that enable them to gain a place in a higher institution. A range of challenges at school level are seen as inhibiting wider access to higher education in Malaysia. The following are the challenges facing public schools in Malaysia.

\section{Enrolments in Primary and Secondary Education}

The government has achieved remarkable success in expanding both primary and secondary education. The number of students enrolled in primary schools has been rising over many decades and the proportion of this age group attending primary schools has stayed above 90 percent since 1980. However, the government has struggled to ensure that all students go on to secondary education. Figure 5 shows the number of children enrolled in primary, lower secondary and secondary education as a percentage of the total population in that age group between 1967 and 2015.

Figure 5: Enrolments in primary and secondary education as a percentage of age group, 1967-2015 (\%)

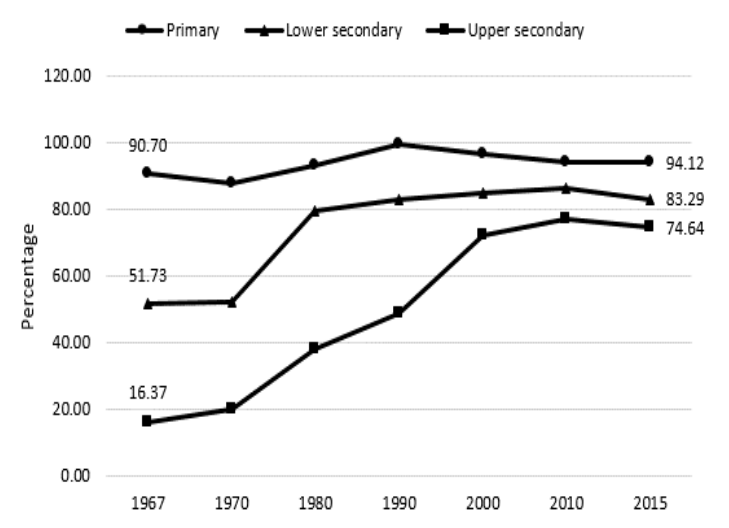

Source: Ministry of Education (1967, 2001, 2010, 2015a)

From the graph above, the most significant rise has been in secondary education (the difference of 58.27\%) where lower secondary enrolment rates rose from 51.73 percent in 1967 to 83.29 percent by 2015, while upper secondary 
enrolment rates grew from 16.37 percent to 74.64 percent over the same period. Primary school enrolment rates, on the other hand, remained fairly stable and generally high, ranging between 88.2 percent and 99.8 percent and surpassing enrolment rates in lower and upper secondary school over the last 48 years. The biggest concern was the downward trend of primary school enrolments from 1990 to 2015 and also secondary enrolments starting in 2010. This indicates that keeping students in the educational system remains a major challenge for the government and access to primary education does not automatically translate into similar access to secondary education.

\section{School Dropout}

The dropout statistic is an important measure to monitor educational outcomes. It assists education policy makers in identifying those groups of students who are in need of support. High dropout rates are likely to indicate the failures of the education system and have major implications for the Malaysian economy. Figure 6 reveals the four states where primary-school dropout rates were highest in 1996 and 2009.

Figure 6: Primary-school dropout rate by state, for selected year 1996 and 2009 (\%)

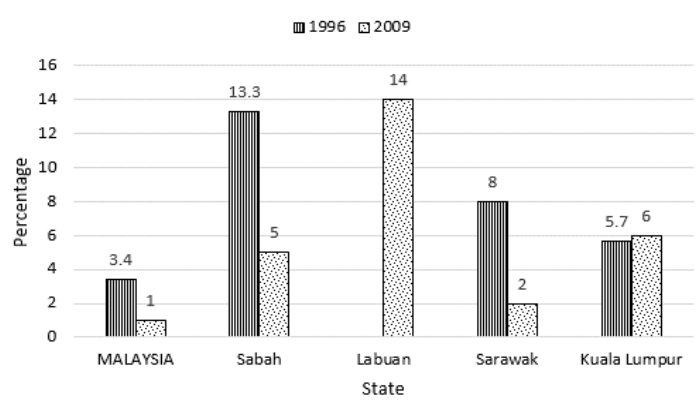

Primary student dropout rates were typically high in Sabah and Sarawak for the year 1996 , decreasing by 2009 , but the rates still remained above the national rate of one percent. One interesting feature of this graph was the Federal Territory of Labuan (F.T. Labuan) had the highest primary dropout rate in the country in 2009. It is important to note that F.T. Labuan was part of Sabah until 2001. Thus, the 2009 dropout rate in Sabah would have been even higher if F.T. Labuan was included in the figure. In addition, it is surprising to see that the Federal Territory of Kuala Lumpur (F.T. Kuala Lumpur) was among the states with highest dropout rates. Again, a possible explanation for this is that F.T. Kuala Lumpur has undergone rapid population growth and urbanization with a large influx of people from other states as well as immigrants from neighbouring countries. However, a graph presents data on secondary-school dropout rate cannot be plotted due to lack of relevant statistics.

\section{Transition Rate}

The Malaysian government has considered extending compulsory education from six to eleven years of schooling, but little attention has so far been paid to make secondary education compulsory. Thus, there are children who leave the system at each level of education. This is shown by looking at the transition rates as the students move from one level of education to the next. The transition rates from primary education to lower secondary education in the period 2006 to 2015 are reported in Figure 7.

Source: Economic Planning Unit (2011),

Table 2.3, page 36 
Figure 7: Transition rates of enrolment from primary to lower secondary level and lower secondary to upper secondary level in government and government-assisted schools, for selected year 2006, 2010 and 2015

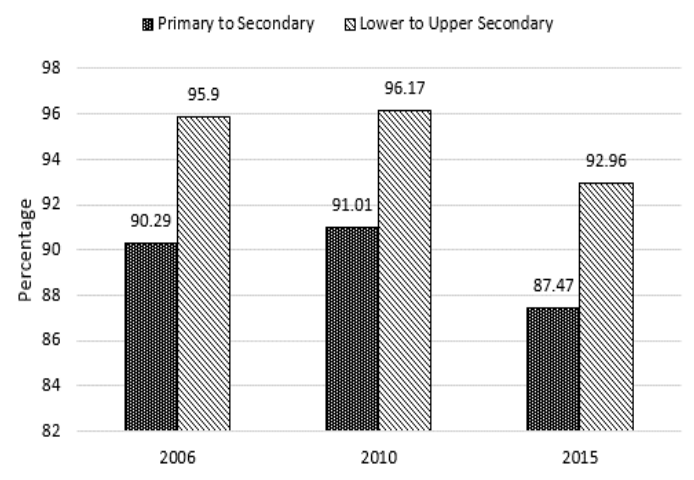

Source: Ministry of Education (2015a)

As shown in this figure, the immediate secondary enrolment rates after finishing primary school in 2006 increased from 90.29 to 91.01 percent in 2010 and declined to 87.47 percent in 2015. The loss of approximately one out of every ten students in 2015 reveals a worrying trend. Although more than 80 percent of students proceeded directly to secondary level in 2015, the poor performing students are more likely to face a greater risk of leaving after finishing lower secondary education. The worst case scenario is that there are students opting out of the education system after completing lower secondary education. The immediate upper secondary enrolment rates increased from 95.9 to 96.17 percent in 2010 and decreased slightly to 92.96 percent in 2015 . Although only 7 percent of students left the education system in 2015 after finishing Form 3, the absolute figure $(33,143$ students) was high enough to represent a significant loss (Ministry of Education, 2015a). The findings above indicate that the issue of young students leaving school without completing their basic education remains a concern. Although the government has achieved a major outcome in reducing the 'bottlenecks' in the system, low transition rates at each level of schooling reduce the number of students pursuing higher educational levels.

\section{Academic Achievement Gap}

The greatest challenge in education is the persistent gap in achievement between urban and rural students. The 2010 and 2011 UPSR (Primary School Achievement Test) reveals that there was a difference among the two groups pertaining to academic performance, but the gap was quite small as illustrated in Figure 8.

Figure 8: UPSR student achievement results by location, 2010 and 2011 (\%)

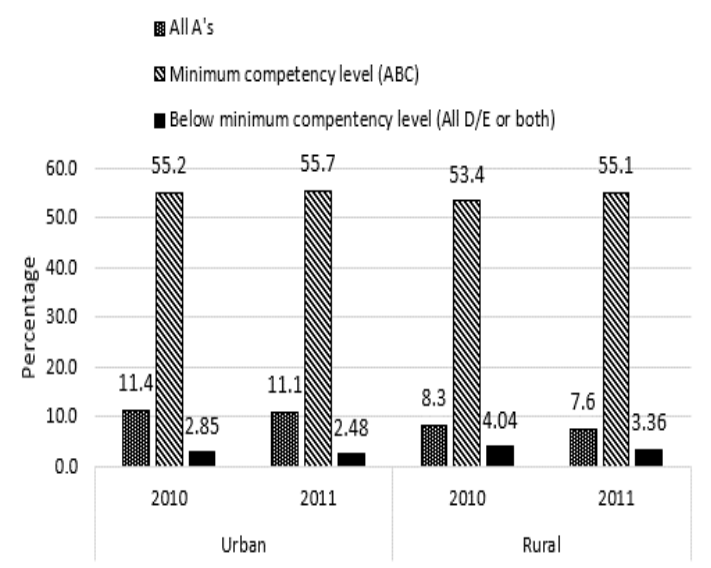

Source: Ministry of Education (2011), Table 2

The 2010 and 2011 UPSR results show that the urban-rural achievement gap has become smaller. In 2011, the urbanrural gaps for UPSR results were 3.5 points for straight $A$ 's in all subjects, 0.5 points for minimum competency level, and 0.9 points for below the minimum competency. This finding reveals that there is a difference among the two groups pertaining to academic performance as early as primary level, but the gap is quite 
small. The disparities in academic performance at primary level have an effect on student achievement and contribute to an even greater gap at upper secondary education level (students are required to take the Malaysia Certificate of Education examination or known as SPM), as illustrated in Figure 9.

Figure 9: SPM student achievement results by location, 2008 and 2009 (\%)

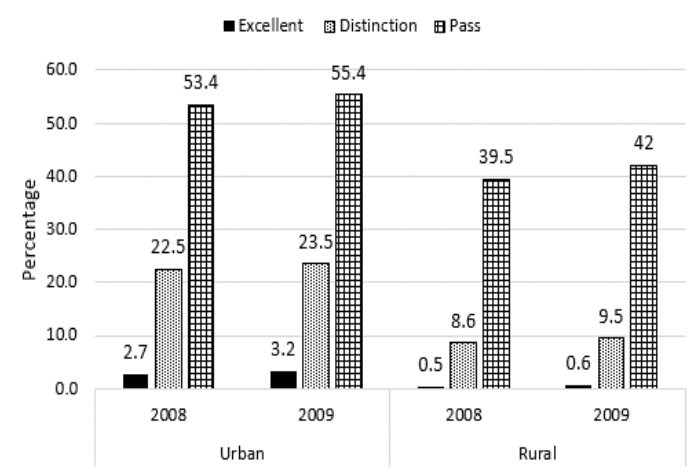

Source: Ministry of Education. (2010)

Note: 1) Excellent refers to Grade A+/A/A-, 2) Distinction refers to Grade C and above, and 3) Passed refers to Grade $\mathrm{D} / \mathrm{E}$

As the chart shows, students in 2009 attained much better results than those in 2008 with both urban and rural students achieving a higher percentage of excellent, distinction and pass rates in 2009. The score gaps between rural and urban SPM candidates, however, were higher than UPSR. In 2008, the urban-rural gaps for SPM results were 2.2 points for excellence, 13.9 points for a distinction, and 13.9 points for a pass. The gap increased slightly in 2009 to 2.6 points for excellence and 14 points for distinction, while the gap for passed shrank to 13.4 points. The Preliminary Report for Malaysia Education Blueprint (20132025) also reported that the performance gap between urban and rural schools was almost 4 percentage points at UPSR level and 8 percentage points at SPM level in the year 2012. This clearly indicates that the gap is still very much a real thing

\section{To Strengthen and Improve Education In Government Schools}

A key to making higher education more effective is to strengthen and improve Malaysia's public schools. First, Malaysia needs to focus on improving access to secondary education. This is because school participation rates decline at the higher stage of schooling. Although primary education has almost achieved universal enrolment (94.12\% in 2015), secondary school attendance is still a concern, given that it is not compulsory in Malaysia at present for school students to attend secondary schools. While enrolments at government secondary schools are growing, not all students proceed to lower secondary level.

Second, Malaysia needs to improve quality and equity in school education. High priority should be given to reducing the rural-urban education gap in terms of academic performance, infrastructure, teaching and learning facilities, and also qualified teaching staff. Many rural schools need more funds for the average student, who mostly comes from a low-income family, in order to raise achievement. Rural, low-income students need experienced and qualified teachers, school counsellors and school leaders, and these professionals in turn deserve to be paid at a higher rate due to additional responsibilities. Building a solid foundation is essential, but the main focus should be on secondary school students because the evidence shows that achievement gaps grow even larger at this level.

Finally, improving teacher quality is the most strategic way to increase academic performance. All schools must be provided with 
well qualified teachers in all subjects. In order to get the right people into teaching, the Ministry of Education needs to set higher entry requirements. Teachers at all school levels must be provided with adequate training and gain plenty of pre-service classroom experience to enhance their skills and knowledge before graduation. This will ensure that all new teachers are meeting a high standard and are committed to delivering excellent teaching for their students. Re-training of teachers is also required to keep their skills and knowledge up to date with the latest teaching techniques. Primary school teachers should be encouraged to get a university education and teachers at secondary schools to obtain a post-graduate degree. By ensuring that all schools are able to provide a high standard of education to their students.

\section{Conclusion}

Malaysia has achieved good progress in developing and strengthening the school system. Since independence, education has been regarded as a key factor driving social and economic development. The result has been a remarkable rise in primary and secondary school enrolments over the past decade. It was a major success for the country when there are many children today finishing their school education and going to university in numbers not seen before.

In another step forward, since the 1990s the government has been expanding the higher education sector and broadening access to higher education institutions. The government, however, is likely to find itself under great pressure in the future to meet the targets and fulfil its plans. The findings in earlier sections have provided strong evidence that after more than 60 years of independence, school education system is still facing many challenges. While public schools are open to all children regardless of their backgrounds, educational access and opportunity for some groups and communities are still limited. Improving all aspects of education from the earliest levels of education is therefore essential before progressing to the next higher levels. The school system must have a strong foundation or 'platform' of improving access, quality and equity in education. This is because school improvement initiatives will most likely lead to increased enrolment in higher education and also contributes to economic development.

\section{References}

Anderson, J. P., Prause, J., \& Silver, R. C. (2011). A Step-by-Step Guide to Using Secondary Data for Psychological Research. Social and Personality Psychology Compass, 5(1), 56-75.

Boslaugh, S. (2007). Secondary data sources for public health: A practical guide. New York: Cambridge University Press.

Economic Planning Unit. (2011). Malaysia: The Millennium Development Goals at 2010. Retrieved 22 November, 2011, from http://www.undp.org.my/files/editor_files/files /Malaysia\%20MDGs\%20report\%20clean\%2 00419.pdf

Ministry of Higher Education Malaysia (2015). Statistics of Higher Education of Malaysia. Ministry of Higher Education Malaysia: Putrajaya

Ministry of Education Malaysia (2015a). Malaysia Educational Statistics. Ministry of Education Malaysia: Putrajaya

Ministry of Education Malaysia (2015b). Malaysia Education Blueprint 2015-2025. Ministry of Education Malaysia: Putrajaya.

Wong, F. H. K., \& Ee, T. H. (1971). Education in Malaysia. (1st ed.). Kuala Lumpur: Heinemann Educational Books (Asia) Ltd. Malaysia. Various Malaysia Plans 
Ministry of Education. (2008). Education in Malaysia: A Journey to Excellence. Putrajaya: Education Planning and Research Department.

Ministry of Education. (1967). Educational Statistics of Malaysia 1938 to 1967. Kuala Lumpur: Dewan Bahasa dan Pustaka.

Ministry of Education. (2001). The Education Development Plan for Malaysia (2001-2010). Kuala Lumpur: Educational Planning and Research Division.
Ministry of Education. (2010). Malaysia Educational Statistics 2010. Putrajaya: Educational Planning and Research Division.

Ministry of Education. (2011). Keputusan UPSR terbaik sejak 2008. Ministry of Education Malaysia: Putrajaya 